Луцький Р. П. Правовий моніторинг процесу формування та розвитку позитивного права...

УДК 342.72

\author{
Роман Петрович Луцький, \\ директор Науково-дослідного інституту \\ імені Академіка Івана Луиького, \\ доктор юридичних наук, доцент \\ Університету Короля Данила
}

\title{
ПРАВОВИЙ МОНІТОРИНГ ПРОЦЕСУ ФОРМУВАННЯ ТА РОЗВИТКУ ПОЗИТИВНОГО ПРАВА (ТЕОРЕТИКО-ІСТОРИЧНИЙ АСПЕКТ)
}

Постановка проблеми. У процесі виникнення і формування засад та витоків позитивного права, його сутність пізнається людьми значно пізніше, ніж виникають і практикою диктуються загальнообов'язкові правила поведінки. Саме ж позитивне право виступає у вигляді конкретно визначених, єдиних за своїм змістом, загальнообов'язкових для всього суспільства правил поведінки, які породжують зміцнення соціальних обов'язків, повинностей, домагань членів суспільства щодо надання їм законних прав та свобод, привілеїв, частки суспільного надбання або плодів власної продуктивної праці. А умови, в яких формується чинне законодавство, дуже тісно пов'язані 3 тими процесами, які відбуваються в державі, оскільки останні, шляхом суперечностей інтересів різних соціальних груп творять таку правову базу, яка відповідає прагненням пануючого класу в соціально-неоднорідному суспільстві.

Саме ці положення визначають актуальність піднятої проблематики.

Аналіз останніх досліджень. Методологічною основою статті стали праці С. С. Алексєєва, В. Д. Бабкіна, В. А. Бачиніна, В. С. Журавського, М. В. Костицького, В. С. Нерсесянца, Н. М. Оніщенко, М. І. Панова, О. Л.Копиленка, Н. М. Пархоменко, С. С. Сливки, Л. Л. Фуллера, Р. О. Халфіна, Ю. С. Шемшученка, які сприяють осмисленню поточних процесів в теорії права та мають важливе значення для подальшого їх дослідження.

Виходячи уже з тих фундаментальних основ, які вони заклали, вважаємо за доцільне провадити власні дослідження визначеної проблематики.

Мета статті. Метою даного дослідження є висвітлення історичних умов виникнення тих засад та витоків позитивного права на основі правильного розуміння визначальних першооснов, які є ключовими факторами в процесі законотворення.

Основні результати дослідження. Офіційне встановлення або визнання норм позитивного права, вираженого в законах та інших офіційних джерелах, відбувається на базі виникнення сформованих умов життя суспільства та діяльності держави, що продиктовані при цьому соціальними потребами, цілями, очікуваннями членів суспільства, організацій людей, органів держави, поступового накопичення досвіду їх задоволення, реалізації та вирішення виникаючих протиріч і т. п.

Будь-яка поява нових потреб, цілей, соціальних ролей та інших важливих умов і фактів, типових для сучасного історичного етапу розвитку суспільства, має на меті також отримати реальне вираження та закріплення у виробничій, соціальній сферах та особистому житті людей, їх спільнот, в діяльності органів держави, перш ніж ці потреби, цілі, ролі отримають загальне визнання і закріплення в законі. Найчастіше такому закріпленню передує їх визнання та підтримка суспільною мораллю, релігією, практикою чиновників, державних службовців або політичними та іншими громадськими організаціями, завдяки чому виникає можливість розгляду питання про правове закріплення законами та іншими рішеннями держави відповідних відносин.

Тому вивчення, становлення та розвиток соціальних процесів, що викликають потребу в правовому регулюванні тих чи інших відносин, $є$ абсолютно необхідною умовою для правильного розуміння особливостей формування позитивного права незалежно від того, відбувається таке формування шляхом спонтанного становлення звичаю, легітимізованого потім державою правовим шляхом, або шляхом поступового накопичення судової практики, релігійних і моральних правил, або шляхом законодавчого встановлення (диктуванням) правових норм державними органами. Звичайно, практика східних деспотій, абсолютних монархій, фашистських режимів та інших форм 
існуючих історичних моделей верховної необмеженої влади включає до свого складу елементи сваволі, навіть прямої розправи з неугодними, ігнорування інтересів народних мас, пряме марнотратство і роздачу почестей та привілеїв наближеному оточенню і т. п. Але при цьому вплив законодавчого свавілля на правопорядок завжди носить випадковий характер, навіть тоді, коли його наслідки можуть були тривалими і дуже тяжкими для народів і держав.

Свавілля, помилки, безглуздості правителів, суддів, парламентів чи законодавчих зборів не можуть розглядатися як діюче право, оскільки вони не створювали правопорядку у відносинах між людьми, правопорядку управління, сталого процесу реалізації суспільних відносин. Тому свавілля в будь-якій його формі, починаючи від указів та наказів фараонів, імператорів, абсолютних монархів і закінчуючи антизаконною творчістю влади та чиновницьким здирництвом, $є$ корисливим елементом, який і породжує найбільше зло для суспільства - загострення протистоянь інтересів.

Для теорії права це лише об'єкт заперечення і показник соціальної шкоди, а не критерій права. Реально виникаючі соціальні потреби і підстави правового регулювання розглядаються в правовій літературі як різні фактори, що обумовлюють процес правового регулювання, його зміни, скасування діючих норм права. Важливо при цьому підкреслити, що мова йде про складові, які формують правотворчий процес і знаходяться, як правило, за правотворчістю держави, при цьому вони детермінують зміст останньої та її результати, тобто саме позитивне право [1, с. 323-324].

Соціальні фактори, що безпосередньо впливають на законотворчий процес, тобто на діяльність держави щодо встановлення або визнання правових норм, необхідно розглядати як передумови правотворчості і позитивного права. Тому видається доцільним охарактеризувати різні соціальні чинники, що впливають на процес формування права, як особливого соціального юридично процесу, який генетично пов'язаний з правотворчою діяльністю держави, але нетотожний самій правотворчості як юридично оформлениму процесу і його результату - позитивному праву [3, с. 148].

Визнання такого соціального процесу, що передує й обумовлює офіційне позитивне право, характерне не тільки для марксистської концепції права, а й для таких великих теоретичних концепцій права, як природне право, історичної, психологічної і в особливості соціологічної школи права, основою якої є теорія інтересу. Загальним для всіх цих правових теорій, основною метою, $є$ пошуки соціальної субстанції, причини, що породжуює норми позитивного права. Ці теорії відомий угорський юрист академік Л. Фуллер характеризує як генетичні концепції, що мають на увазі чинники, які $є$ причиною появи правових норм, на відміну від юридичного позитивізму, що орієнтується на розкритті всього того, що допомагає виявити правовий характер правил поведінки і нічого більше [5, с. 141].

Марксистська концепція права належить, поза сумнівом, до генетичних концепцій, але на відміну від інших, схожих $з$ нею теоретико-правових підходів, вона грунтується на економіці, тобто розвитку виробничих сил та технічних потужностей, при цьому основна увага акцентується на класовому підході щодо характеристики суспільства. Ця концепція визначальне значення приділяє соціальним чинникам під час формування позитивного права.

Відомі юристи-теоретики права, характеризуючи правові доктрини, поряд з основоположними, базисними чинниками право творення, важливе значення приділяли матеріальним та іншим об'єктивним обставинам, до яких відносили умови життєдіяльності суспільства, інтереси пануючого класу або всього народу, ідеологічні, соціально-психологічні уявлення та вольові прагнення класів, тобто суспільну свідомість, яка виражає інтереси різних класів і верств населення [4, с. 96]. Серед суб'єктивних, тобто ідейних і психологічних факторів формування позитивного права підкреслювалося важливе значення правової свідомості особистості, а також формування волі класів, які стоять при владі або прагнуть заволодіти нею. Нарешті, особливо акцентувалась увага на формуванні державної волі шляхом нав'язування пануючим класом свого інтересу, яка $\epsilon$ ніби завершальною та визначальною сходинкою соціального процесу формування права, створення державою правових юридичних норм, тобто власне юридично оформленим процесом правотворчості.

У літературі минулого століття розроблявся і дещо інший підхід щодо розуміння визначальних факторів процесу правотворчості (наприклад, в монографії «Наукові основи радянської правотворчості»). Автори цієї праці в загальному аналізували та визначали приблизно такі об'єктивні і суб'єктивні чинники процессу формування права, як:

- пріоритетне значення економічних факторів для виникнення правової надбудови;

- формування інтересів і волі пануючого класу;

- обумовленість правової форми змістом суспільних відносин;

- внутрішню узгодженість норм права; 
- об'єктивну обумовленість співвідношення засобів правового регулювання;

- соціально-політичні фактори правотворчості, в тому числі роль КПРС у виробленні правової політики, та участь мас у процесі правотворчості;

- формування потреб в правовому регулюванні у діяльності суб’єктів законодавчої ініціативи, а також в стадії розробки законопроекту [2, с. 220]. У монографії піднімались й інші важливі проблеми правотворчості: прогнозування, планування правотворчості, законодавча техніка й ін.

Усі ці проблеми, безсумнівно, мають відношення до правотворчості, як визначальної діяльності держави.

Не вказуючи на цілий ряд недоліків даної монографії, що були притаманними в рівній мірі всім роботам радянського періоду, оскільки неминуче виставляли на перший план переваги соціалізму і його права, керівну роль партії, іiі непомильності та можливість знайти відповіді на всі питання життєдіяльності в теоретичних основах класиків марксизму-ленінізму, зовсім не правильно всіляко відсторонювались або відхрещувались від проблематики, яка декларувалася демократичними правовими теоріями. Відзначимо лише той аспект запропонованого підходу, який цікавить нас саме в сучасних умовах.

Так, автор першої глави названої книги проф. Р. О. Халфина виходила з того, що поняття правотворчості $є$ науково обгрунтованим процесом, який представляє собою форму державного керівництва суспільством, що завершує процес формування права і відображає лише соціальні чинники цього процесу... [2, с. 58]. Але якщо це так, то, по суті, мова повинна була йти не про всі соціальні явища, які існують в суспільстві, а лише ті, які враховуються та реалізуються в правотворчій діяльності держави.

Тим часом Р. О. Халфина прагнула за критерієм значимості охопити більш широке коло тенденцій, які впливають на процес законотворення, включаючи сюди всі процеси, що передують рішенню про підготовку проекту нормативного акта та виражають потреби в правовому регулюванні. Такий підхід охоплював реальні життєві елементи, процесу правотворення, які мають бути проаналізовані та, згодом, відображені під час законодавчої діяльності держави. Але основні вимоги і потреби, які обумовлюють прийняття закону та позитивного права, слід шукати не лише в самій правотворчості, а швидше в об'єктах і цілях встановленого державою позитивного права. Пізнання, аналіз, науковий підхід до правотворчості безсумнівно необхідні для законодавчої діяльності держави, але ці важливі засоби публічної діяльності не слід ототожнювати з самим соціальним процесом формування норм права. Державна правотворчість лише завершує і відображає вплив на формування норм права з боку економіки, політики, конкретних інтересів і уявлень про право, що формуються через умови, продиктовані способом життєдіяльності, які згодом закріплюються законом та виражаються в формі позитивного права.

Допущені ж авторами названої книги змішання понять «пізнання», «вивчення», «виявлення» соціальних факторів у процесі правотворчості з реальним існуванням і впливом соціальних процесів життя суспільства та різноманітної діяльності держави не дало можливості розкрити і виділити сутність самого поняття «соціальний процес формування права», на відміну від його завершальної стадії - юридичного процесу правотворчості, який безпосередньо породжує норми чинного позитивного права.

Висновки. Отже, з впевненістю можемо заявити, що історичні умови виникнення позитивного права формувалися через призму соціальних інтересів тих прошарків, які знаходились біля державного апарату. Ці обставини давали можливість приймати такі управлінські рішення, які краще б захищали їхні майнові права та можливості через призму формування позитивного права, яке має загальнообов'язковий характер для всього суспільства. Тому, підсумовуючи вищенаведені положення, з впевненістю можемо заявити, що умови, засади та витоки чинного законодавства формуються в процесі взаємодії різних соціальних класів суспільства та закріплюються під впливом інтересів елітних прошарків, які шляхом формування загальнообов'язкових норм поведінки створюють для себе привілейовані умови гри.

\section{Список використаних джерел}

1. Алексеев С. С. Линия права. Москва: Статут, 2006. 461 с.

2. Гаврилов О. А., Колодаєва Н. П., Пиголкин А. С. и др. Научные основы советского правотворчества: Отв. ред. Халфіна Р. О.; Академия наук СССР. Институт государства и права. Москва: Наука, 1981. 317 с. 
3. Лазарев В. В., Липень С. В. Теория государства и права: учебник для вузов. 3-е изд., перераб. и допол. Москва: Спартак, 2004. 527 c.

4. Трубецькой Е. Н. Лекции по энциклопедии права. Москва: Из-во А. И. Мамонтова, 1977. 227 с.

5. Фуллер Л. Л. Анатомія права: наук видання / пер. з англ. Н. Комарова. Київ: Сфера, 1999. 144 с.

\section{References}

1. Alekseev S. S. Line of law. Moscow: Statute, 2006. 461 p.

2. Gavrilov O. A., Kolodayeva N. P., Pigolkin A. C. and others. Scientific fundamentals of Soviet lawmaking: Otv. edit Halfina R.O.; Academy of Sciences of the USSR. Institute of State and Law. Moscow: Nauka, 1981. 317 p.

3. Lazarev $V$. V., July S.V. Theory of state and law: a textbook for high schools. 3rd ed., Pererab. and supplement Moscow: Spartak, 2004. 527 p.

4. Trubetskoy E. N. Lectures on Encyclopedia of Law. Moscow: From A. I. Mamontov, 1977. 227 p.

5. Fuller L. L. Anatomy of Law: Science Edition / per. from english N. Komarova. Kyiv: Sphere, 1999. 144 p.

\section{Луцький Р. П. Правовий моніторинг процесу формування та розвитку позитивного права (теоретико-історичний аспект)}

Метою дослідження є визначити основні етапи, які пройшло чинне законодавство в процесі своєї еволюції. А також акцентувати увагу на тому, що на початку розвитку людства право існувало у вигляді «звичаю» (звичаєвої нормативної системи), з якого в процесі свого розвитку сформувалося сучасне «чинне законодавство» (позитивне право). Яке характеризується складними ієрархічними зв'язками та особливими правилами прийняття. Методологія дослідження спирається на принципи історизму, системності, науковості, міждисциплінарності. Використано такі загальноісторичні методи: історіографічний аналіз, історико-генетичний, термінологічний аналіз, компаративний, типологічний. Наукова новизна виражається в тому, що на основі широкого кола опублікованих і неопублікованих досліджень у сфері принципів формування права нами було систематизовано та обгрунтовано формулу причинно-наслідкових зв’язків, які в підсумку здійснили визначальний вплив на сучасне позитивне право.

Ключові слова: суспільство, держава, позитивне право, природне право.

Lutcky R. P. Legal monitoring of the formation and development of positive law (theoretical-historical aspect)

The aim of the research is to identify the main stages that the current law passed in the course of its evolution. And focus attention that in the beginning of the development of humanity law existed in the form of «custom» (the customary normative system), from which in the process of its development formed a modern «current law» (positive law). Which is characterized by complex hierarchical connections and special rules of acceptance. The research methodology is based on the principles of historicism, systemicity, science, interdisciplinary. The following general-historical methods have been used: historiographical analysis, historical-genetic, terminological analysis, comparative, typological. The scientific novelty of the basis of a wide range of published and unpublished researches of in the sphere of the principles of the formation of law we have systematized and substantiated the formula of cause-effect relationships, which ultimately made a decisive influence on modern positive law.

Conclusions. The current law, as well as the formation of the state, has undergone a significant historical path of its formation and development from the primitive custom to the established positive law of the state. At the same time, in the early states, the customary way of legal regulation prevailed, even under persistent and ever-strengthened attempts by public authorities to influence the legal life of the contemporary society and dominate it through the judicial and administrative apparatus.

The very origins and principles of the current legislation can be found in the social regulation of the primitive society, which was carried out, first of all, with the help of customs, taboos, morals, etc. At the same time, the main principles of customary law as the first form of positive law were mythological and religious principles, which also evolved and were supplemented in the process of further development of its forms. The origins of the current legislation, which reflect the historical beginning of its phased formation and development, are different in certain time and social terms.

As for the current law, it arose in the conditions of gradual and long-term formation of socially heterogeneous society, as well as development, first of all, socio-economic relations. At the same time, the historical conditions of the emergence of the officially established modern positive law, that is, the law of law, are formed, including, and through the prism of social interests, layers close to the state apparatus. These circumstances made it possible to make such managerial decisions that would better protect their property rights and opportunities through the prism of the formation of positive law, which has a universal character for the whole society.

Key words: society, state, positive law, absolute law.

DOI: 10.33.66.3/2524-017X-2019-10-57-60 